\title{
The contestations of diversity, culture and commercialization: why tissue culture technology alone cannot solve the banana Xanthomonas wilt problem in central Uganda
}

\author{
Lucy Mulugo $^{1}$ (D) Paul Kibwika ${ }^{1} \cdot$ Florence Birungi Kyazze $^{1} \cdot$ Aman Omondi Bonaventure $^{2} \cdot$ Enoch Kikulwe $^{3}$
}

Accepted: 3 February 2022 / Published online: 3 March 2022

(c) The Author(s) 2022

\begin{abstract}
Several initiatives by the Government of Uganda, Research Institutes and CGIAR centers have promoted the use of tissue culture (TC) banana technology as an effective means of providing clean planting material to reduce the spread of Banana Xanthomonas wilt (BXW) but its uptake is still low. We examine factors that constrain uptake of tissue culture banana planting materials in central Uganda by considering the cultural context of banana cultivation. Data were collected using eight focus group discussions involving 64 banana farmers and 10 key informant interviews and subjected to thematic analysis. Results showed that banana cultivars in the study communities were important for food, cultural practices and medicine. Cultivars supplied through TC were based on commercial considerations focusing on market value and household income and insufficient attention was given to their cultural importance. Farmers regard banana from TC planting material to be incompatible with their tastes and preferences for traditional food and drinks, culture and medicine. Furthermore, the plantlets are perceived as complicated to use, and farmers report requiring more knowledge and information on how to plant and maintain the plantlets on-farm. In these aspects, TC planting material does not align with cultural values linked to societal welfare. Future efforts aimed at controlling pests and diseases would benefit from more location-specific and holistic approaches that integrate cultural dimensions alongside planting material hygiene, quality and vigor.
\end{abstract}

Keywords Banana tissue culture planting material $\cdot$ Cultural values $\cdot$ Diversity $\cdot$ Banana Xanthomonas Wilt (BXW) Technology uptake

Lucy Mulugo

Lucy.mulugo@mak.ac.ug

Paul Kibwika

Paul.kibwika@mak.ac.ug

Florence Birungi Kyazze

fbirungikyazze@gmail.com

Aman Omondi Bonaventure

b.a.omondi@cgiar.org

Enoch Kikulwe

e.kikulwe@cgiar.org

1 Department of Extension and Innovation Studies, School of Agricultural Sciences, College of Agricultural and Environmental Sciences, Makerere University, P.O Box 7062, Kampala, Uganda

2 Benin - Bioversity International C/O IITA/Benin Research Station, 08 B.P. 0932 Cotonou, Benin

3 Uganda - Bioversity International, Plot 106, Katalima Road, P.O. Box 24384, Naguru, Kampala, Uganda

$\begin{array}{ll}\text { Abbreviations } \\ \text { AGL } & \text { African Great Lakes } \\ \text { BX } & \text { Banana Xanthomonas Wilt } \\ \text { CGIAR } & \begin{array}{l}\text { Consultative Group on International Agricul- } \\ \text { tural Research }\end{array} \\ \text { CIAT } & \text { Centro International de Agropecuria Tropical } \\ \text { EAHB } & \text { East African Highland Bananas } \\ \text { FGDs } & \text { Focus Group Discussions } \\ \text { FHIA } & \begin{array}{l}\text { Fundación Hondureña de Investigación Agrí- } \\ \text { cola } \text { In Honduras (Honduras Foundation for }\end{array} \\ & \begin{array}{l}\text { Agricultural Research) } \\ \text { GM }\end{array} \\ \text { Genetically Modified } \\ \text { IITA } & \text { International Institute of Tropical Agriculture } \\ \text { LC } & \text { Local Chairperson } \\ \text { NGOs } & \text { Non-Governmental Organization } \\ \text { TC } & \text { Tissue Culture }\end{array}$




\section{Introduction}

Banana (Musa spp.) is a staple and cash crop in the East African region with over 30 million people depending on the crop for food and income (Dotto et al. 2019). The crop highly nutritious, providing a good source of carbohydrates, vitamins ( $\mathrm{A}, \mathrm{B}_{1}, \mathrm{~B}_{2}, \mathrm{~B}_{6}$, and $\mathrm{C}$ ), minerals (potassium, iron, zinc, calcium, phosphorous, magnesium and selenium), polyphenols, resistant starch, and antioxidants (Hardisson et al. 2001; Haslinda et al. 2009). Banana is a major staple for more than a half of Uganda's population. The average national per capita annual consumption of bananas is estimated at close to $1 \mathrm{~kg}$ per person per day, the highest in the world (Edmeades et al. 2015). The crop occupies the largest cultivated area (about $30 \%$ of cropland) on plots of less than 0.5 ha (Ngambeki et al. 2003; Edmeades et al. 2015). Banana cultivation in Uganda is dominated by the locally evolved clones known as the East African Highland bananas (EAHB) (Gold et al. 2002), which include the harder green cooking bananas locally called "matooke". Matooke is the leading staple food with an annual production of over 6 million tonnes (Kilwinger et al. 2019). The crop also provides a wide range of products (animal feeds, charcoal briquettes, crafts, and construction materials) which significantly contribute to food and income security of the populace and consequently to national development (Kikulwe et al. 2018).

Banana Xanthomonas Wilt (BXW) disease, caused by the bacterium Xanthomonas campestris pv. musacearum, is currently an important threat to banana production in East and Central Africa (Kikulwe et al. 2019). The disease can cause up to $100 \%$ yield loss where highly susceptible genotypes dominate the farming systems, severely compromising food security and livelihoods for banana-based farming households (Kubiriba et al. 2012; Cori et al. 2018). This disease has no cure and has been a main reason for poor yields since its emergence in the African Great Lakes (AGL) region in 2001 (Tushemereirwe et al. 2004; Kubiriba and Tushemereirwe 2014). In Uganda, the disease was first reported in Mukono District, Central Uganda in 2001 (Tushemereirwe et al. 2004) and by 2005 it had rapidly spread to South Western Uganda, the major banana producing areas. Between 2002-2005, the disease caused a cumulative economic loss of 61.1 million dollars by the country, mainly affecting EAHB, 'Matooke' (AAA-EAHB genome) and the 'Kayinja' beer banana (ABB genome) (Tushemereirwe et al. 2009). According to McCampbell et al. 2018, the disease is also of prominent importance in neighboring banana producing countries, namely: Burundi, Kenya, the Democratic Republic of Congo, Rwanda, and Tanzania.

The causative bacterium Xanthomonas campestris $p v$. musacearum is highly transmissible mainly through infected plant material, contaminated farm tools and soil, trade of banana and its products, and occasionally through vectors such as insects, birds, and bats (Blomme et al. 2014; Ocimati et al. 2019) (Fig. 1). The mode of spread varies significantly based on the production system, agroecology and cultivars grown. All cultivars grown in the Great Lakes region of Eastern Africa are susceptible, and no source of resistance has been identified (Kalyebara et al. 2007; Tripathi et al. 2009; Kubiriba and Tushemereirwe 2014). Figure 1 illustrates the transmission pathways of the bacterium.

Over the past 16 years, various research and extension efforts at global, national and local echelons have converged to manage and contain the disease (Ocimati et al. 2019; Gotor et al. 2020). Epidemiology studies of BXW (e.g., see Blomme et al. 2005, 2017; Kubiriba et al. 2012; Nakato et al. 2015; Ocimati et al. 2015) informed control strategies including farmers sensitization and development and enforcement of bylaws for control of the disease (Kubiriba et al. 2012; Blomme et al. 2014). These efforts, however, have not been effective for landscape-wide control of BXW. Once the disease is established, its eradication has proved difficult (Eden-Green, 2004; Ocimati et al. 2019) due to inappropriate recommendations for agronomic and/or technical practices ${ }^{1}$ (Karamura et al. 2008). Some farmers do not adhere to these recommendations due to the associated high labor cost and perceptions about the management practices (Jogo et al. 2013; Uwamahoro et al. 2019). Farmers are usually reluctant to employ labor-intensive and costly disease control measures (Namukwaya et al. 2011). These practices require regular monitoring, adding to the labor and time burden for the farmer. This compromises BXW eradication, resulting in farmers' reluctance to apply the recommended practices. Consequently, systematic application of such control practices is frequently done in large-sized households (Mbabazi et al. 2021).

Establishing banana plantations with clean (pathogenfree) seed $^{2}$ is the most effective way to manage the BXW (Also see Thomas-Sharma et al. 2016). This has led to popularization of Tissue Cultured (TC) plant material as a response strategy to supply disease-free seed and enhance productivity (Dubois et al. 2013; Mulugo et al. 2020). In this aspect, TC banana epitomizes many of the principles of the New Green Revolution of Africa ${ }^{3}$ (Vercillo et al.

\footnotetext{
${ }^{1}$ Such as timely removal of male buds with a forked stick, disinfection of farm tools, removal of infected plants and use of clean planting materials.

2 Seed, TC banana planting materials and TC banana plantlets are used interchangeably throughout the manuscript.

3 There are a host of environmental, health and social consequences of Green Revolution technologies, widely documented, which have implications for both food consumption and nutrition inadvertently leading to low uptake of such technologies in Africa (see Kerr 2012; Rock and Schurman 2020).
} 
2015; Schnurr 2019). It is a form of micro-propagation that allows for replicating, regenerating, and rapid/y disseminating planting materials that are genetically identical and disease free (Kikulwe, 2016). Tissue Culture encapsulates a new paradigm of agricultural development efforts, in which its promoters have stepped in to address crop productivity failure by investing in the technology to manage and contain crop diseases whilst expanding farmers' livelihood opportunities, especially amongst vegetatively-propagated crops such as banana (Schnurr 2019). Therefore, adoption of TC seed has been collaboratively promoted by the Ministry of Agriculture Animal Industries and Fisheries, National Agricultural Research Institutes, CGIAR centers and private institutions (Mulugo 2021).

However, the penetration of TC banana planting materials is reportedly low-only 7\% of national plantings (Dubois et al. 2013), with reported highest levels (19.3\%) in the western region (Mmurongo et al. 2018). Reluctance by farmers to take up TC planting materials has to-date been explained by economic factors namely: access and high cost of plantlets, labor costs and input requirements (Kabunga et al.2012; Njau et al. 2011). Without discounting the importance of these factors, they do not sufficiently embed banana cultivation in the cultural values and practices of central Uganda built on cultivar diversity. The economic perspective alone for example, cannot adequately explain the low uptake of TC planting materials among commercially-oriented farmers whose aim is supposedly to maximize productivity. In central Uganda, bananas are not only a commercial food crop, but also a cultural artefact. Values and cultural attachments to specific banana cultivars construct a contextual setting around the banana production system in Central Uganda that needs to be considered while assessing uptake of TC planting materials. In other circumstances, it has been shown that uptake of agricultural innovations in farming systems is influenced by cultural values (Warren et al. 2016), that are deeply ingrained in societal norms, belief systems, behavioral patterns and the way of life (Idang 2015). Whereas promotion of TC planting materials has focused on supplying a few commercial cultivars that can offset the labor and input costs, these cultivars do not meet the diverse cultural interests of farmers in central Uganda. Literature shows that though there are several drivers of TC technology adoption including economic, climatic and agronomic, there is scant emphasis on cultural aspects that may influence uptake of the technology. This study therefore contributes to the known literature by assessing the cultural context/dimension influencing uptake of TC technology using TC banana. We unravel critical cultural aspects of relevance in the enhancement, use and acceptance of TC technology by farmers in central Uganda.

\section{Methodology}

\section{Study area}

The study was conducted in central Uganda where banana production is anchored in cultural values and practices beyond food and income. Bananas have been grown for centuries in central Uganda (Lwandasa et al. 2014) then spreading to Western and South-western Uganda largely as a commercial crop. It is estimated that about $58 \%$ of agricultural households in central Uganda grow bananas (Uganda Census of Agriculture 2010) for multiple purposes. The study was carried out in Luwero and Mukono districts, where TC banana seed has been promoted by the International Institute of Tropical Agriculture (IITA), Bioversity International ${ }^{4}$ and private institutions (e.g. Agro-Genetic Technologies Limited, Biocrops Uganda Limited) for more than a decade. Despite this the region still continues to experience high BXW prevalence (Ocimati et al. 2015). The two districts pioneered community-based TC banana nurseries to facilitate farmer access to TC seed. The community nurseries were linked to TC laboratories that supplied the materials. Villages that hosted community nurseries were targeted on assumption that proximity enhances access to and hence uptake of TC banana plantlets. Nambi and Gonve villages in Luwero and Mukono districts respectively were the study sites (Fig. 2). The two were the pioneer villages where community TC nurseries and TC demonstration gardens were established.

\section{Research Design and data collection}

A qualitative study design was developed to better understand the cultural values, traditions, beliefs and practices associated with banana cultivation in the study communities. The purpose of this study is to go beyond commercial, economic and agronomic aspects such as cost of plantlets, and begin to understand how farmers think and understand what they do.

Focus Group Discussions (FGDs) and key informants' interviews were used to collect data between August 2016 and February 2017. Village leaders (Local Council I [LC 1] Chairpersons) provided a list of farmers who had accessed TC banana seed. Farmers who had not accessed TC planting materials were excluded from the study as they were presumed not to have experience with the materials. From

\footnotetext{
${ }^{4}$ Bioversity merged with the Centro International de Agropecuria Tropical (CIAT) in a research centre Alliance (https://www.biove rsityinternational.org/alliance/) in 2020, and subsequently officially became part of the One CIAR in 2022 (https://www.cgiar.org/foodsecurity-impact/one-cgiar/).
} 
Table 1 Proportion of focus group participants by location and sex

\begin{tabular}{lllll}
\hline Location & \multicolumn{2}{l}{ Number of FGDs by sex } & Participants & Number \\
\hline Village: Nambi & Male & Female & Male (16) and female (16) farmers & 32 \\
Luwero district & 2 & 2 & & \\
Village: Gonve & 2 & 2 & Male (16) and female (16) farmers & 32 \\
Mukono district & & & & 64 \\
Total & 4 & 4 & &
\end{tabular}

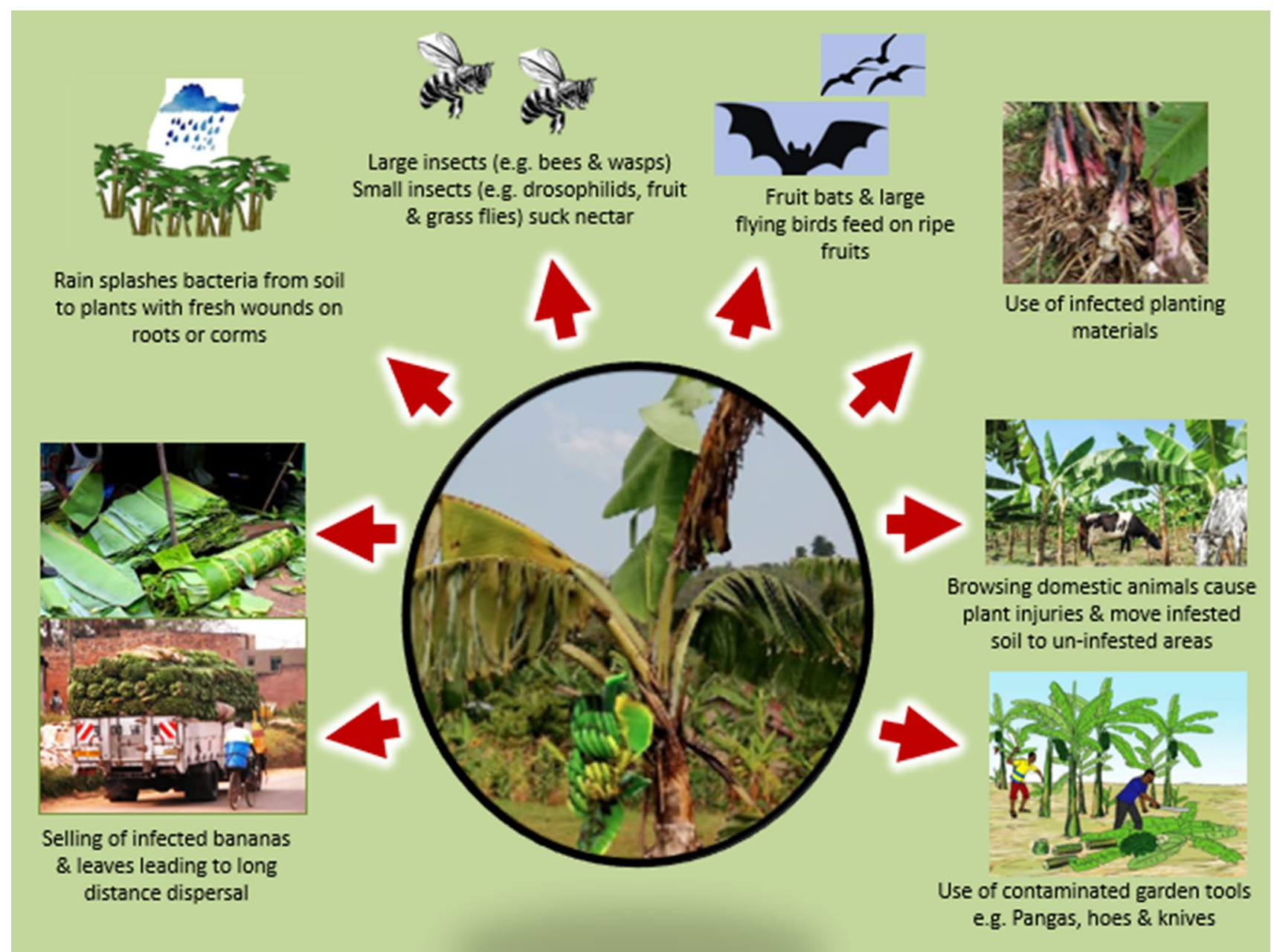

Fig. 1 Transmission pathways for the bacterium Xanthomonas campestris pv. Musacearum causing BXW

the list for each village, the village leaders helped identify 32 farmers ( 16 male and 16 female) who could participate in the FGDs and transmit their experiences. FGDs were conducted in each village guided by a checklist (attached) separately for male and female farmers. Gender segregation was necessary to allow freedom of expression (Braga 2001). For effective discussion and involvement of all FGD participants, two FGDs for male and female farmers were conducted each FGD involving eight farmers as summarized in Table 1 . The intention was to generate diverse cultural practices, beliefs and values from the perspectives of male and female farmers. Farmers were also questioned to determine whether or not they had observed any differences between using TC seed and banana suckers. Farmer responses were noted based on their consensus about the expressed views, explanations, attributes, ideas or reasons.

Based on the interactions of the researchers with farmers during FGDs, ten key informants (4 male and 6 female banana farmers from both villages) were identified (based on their wealth of knowledge and ability to articulate issues) for follow-up to obtain more in-depth information and clarification on the cultural practices and rituals performed associated 


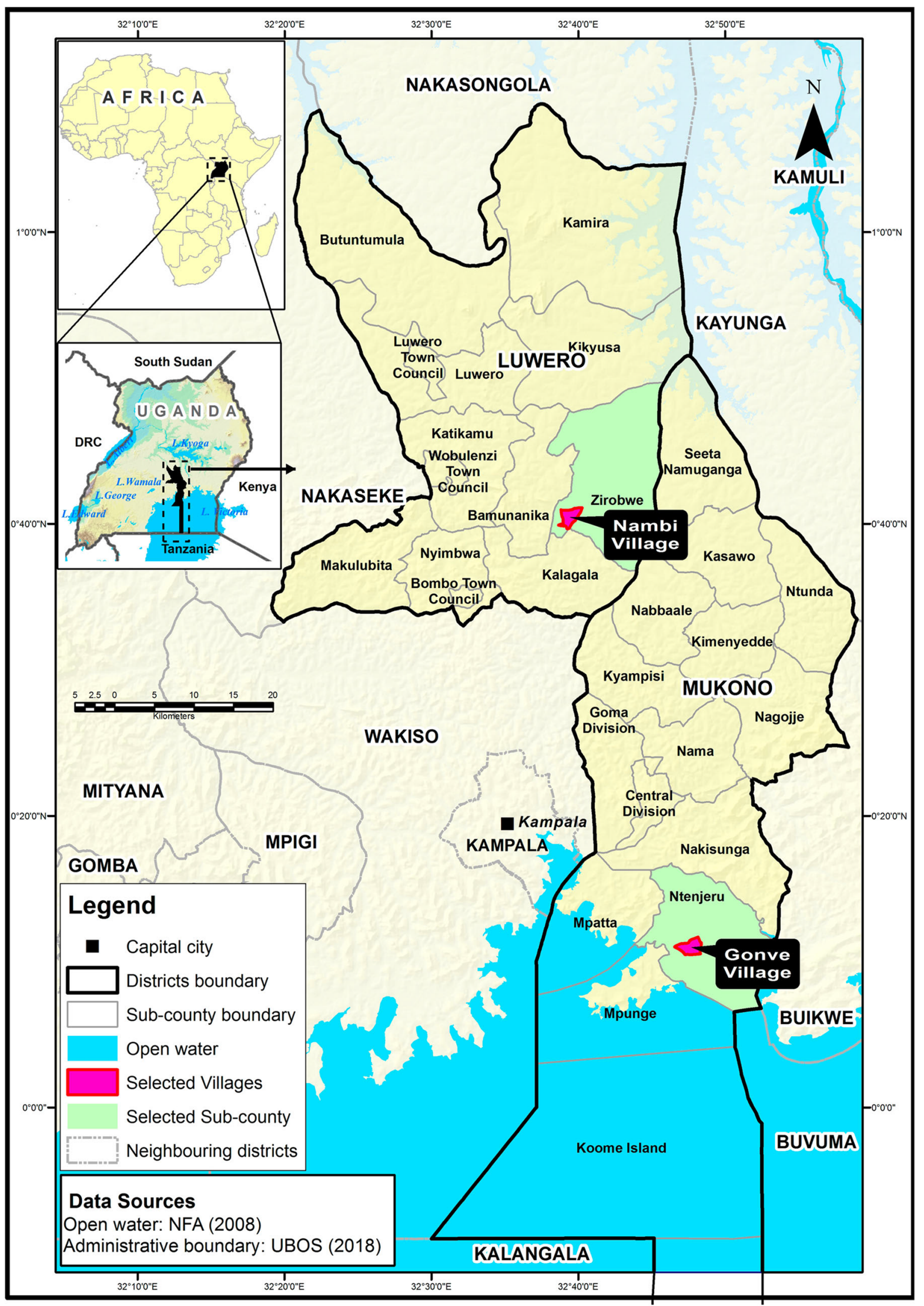

Fig. 2 Location of study villages 


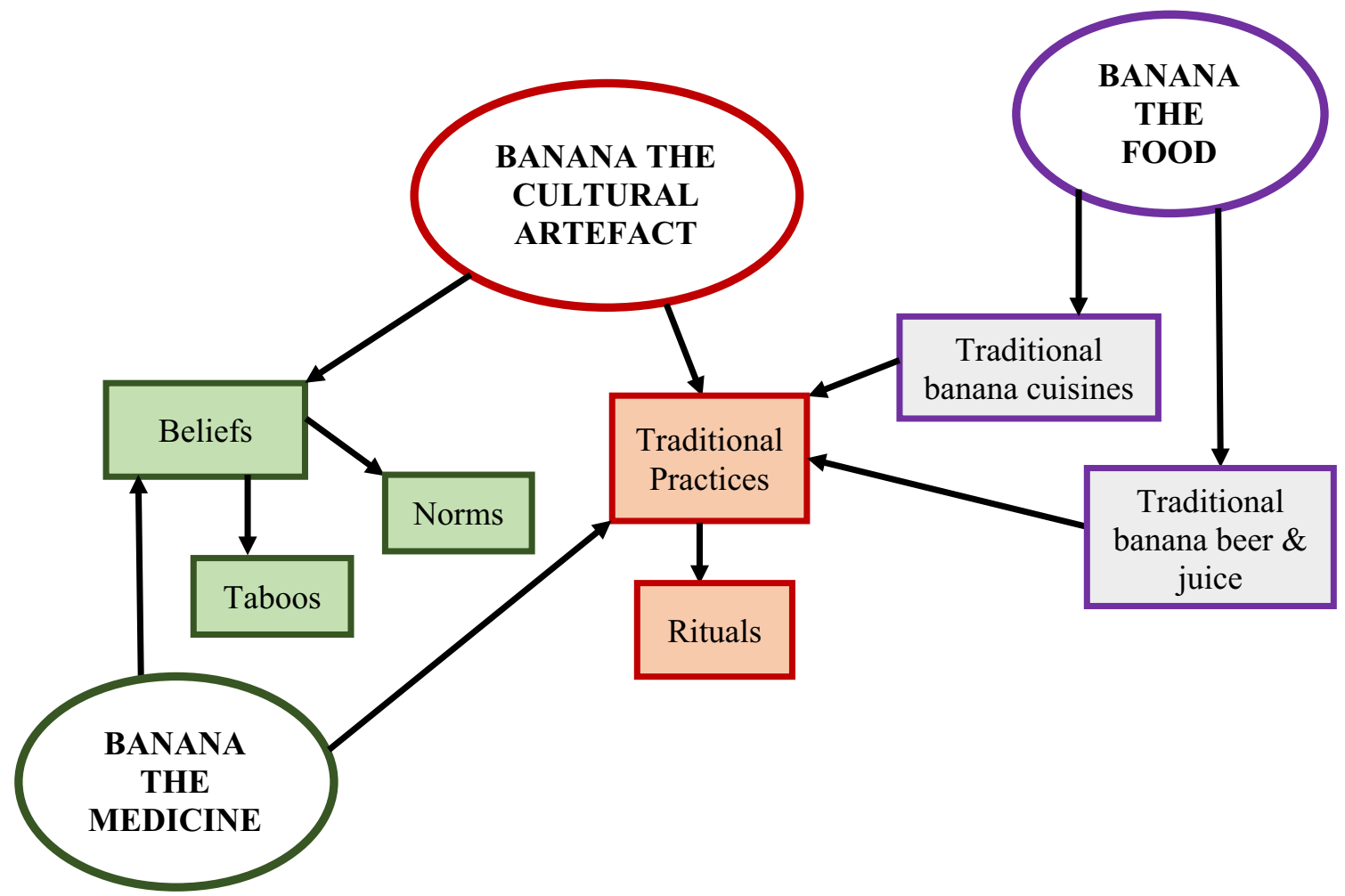

Fig. 3 Thematic map of uses of bananas in the Baganda culture

with different banana varieties. The interviews were conducted in the local language (Luganda) and recorded using a digital recorder for accurate capture of the narratives. Photographs illustrating cultural practices were taken for visualization.

\section{Data analysis}

The narratives were translated from Luganda to English and transcribed for analysis. Thematic-content analysis as described by Braun and Clarke (2006) was applied. Specifically, (i) chunks of data with similar information were clustered; (ii) initial codes for each chunk of data generated using the inductive coding approach (Chandra and Shang 2019); and lastly, (iii) themes were synthesized, reviewed, described and named. A thematic network (Fig. 3) was drawn to illustrate the relationships between, and interrelatedness of the themes developed. The works of Karamura et al. (2012) and Hamilton et al. (2016) were used to categorize the banana cultivars found in the study communities (by clone sets, genomes and genome groups).

\section{Results and discussion}

Three themes emerged regarding the major uses of banana in central Uganda: Banana as food; Banana as a cultural artefact; and Banana as medicine (Fig. 3). The uses are inter-related though specific cultivars are associated with or preferred for each use.

\section{Banana cultivars and their cultural uses}

Forty-five banana cultivars were found to be grown by farmers in the two villages studied (Table 2). The diversity of cultivars is also associated with the wide range of uses and preferences. Farmers usually grow several in the same garden partly to accommodate critical values/needs as explained later in this paper. With regard to use, cultivars are generally categorized as: cooking banana-commonly 
Table 2 Banana cultivars grown in Gonve and Nambi communities in central Uganda

\begin{tabular}{|c|c|c|c|c|}
\hline Banana varieties & Clone set & Genome & Genome Group & Major Use \\
\hline $\begin{array}{l}\text { Kisansa }+ \\
\text { Mpologoma }+ \\
\text { Mpologoma omukadde } \\
\text { Musakala }+ \\
\text { Muvubo* } \\
\text { Namunwe } \\
\text { Mayovu* }\end{array}$ & Musakala & East African Highland & AAA-EA & Cooking \\
\hline $\begin{array}{l}\text { Mbwazirume } \\
\text { Nakamali } \\
\text { Nakitembe }+ \\
\text { Nalugolimo } \\
\text { Nandigobe } \\
\text { Nasalugiri-Soola mwana } \\
\text { Wakirigga } \\
\text { Nabununike }\end{array}$ & Nakitembe & East African Highland & AAA-EA & Cooking \\
\hline $\begin{array}{l}\text { Kibuzi+ } \\
\text { Mukubyakonde* } \\
\text { Nakabululu } \\
\text { Nakyetengu* }\end{array}$ & Nakabululu & East African Highland & AAA-EA & Cooking \\
\hline $\begin{array}{l}\text { Atwalirannyina } \\
\text { Katwalo } \\
\text { Lusumba } \\
\text { Muziranyama } \\
\text { Nabusa } \\
\text { Nakabinyi } \\
\text { Nakawere* } \\
\text { Nakinyika } \\
\text { Nambi* } \\
\text { Namwezi* } \\
\text { Ndibwabalangira } \\
\text { Nfunka+ } \\
\text { Siira* } \\
\text { Kyesusa }\end{array}$ & Nfuuka & East African Highland & AAA-EA & Cooking \\
\hline $\begin{array}{l}\text { Embidde enganda } \\
\text { (Kabula \& Nsowe)* }\end{array}$ & Mbidde & East African Highland & AAA-EA & Juice/Brewing \\
\hline Improved Ndiizi+ & & & & Dessert \\
\hline Bogoya & & Gros Michel & AAA & Dessert \\
\hline FHIA $-17+$ & & Tetraploid hybrids & AAAA & Cooking \& Dessert \\
\hline FHIA $-01+$ & & Tetraploid hybrids & AAAA & Cooking \\
\hline FHIA $25+$ & & Tetraploid hybrids & AAAA & Juice/brewing \\
\hline KM5(Kabana 5)+ & & & & Dessert \\
\hline Gonja (Nakatansese \& Manjaya) + & & Plantain & $\mathrm{AAB}$ & Roasting \\
\hline Kayinja & & Pisang Awak & $\mathrm{ABB}$ & Brewing \\
\hline Kisubi & & Ney Poovan & $\mathrm{AB}$ & Brewing \\
\hline Кіvииขи & & Bluggoe & $\mathrm{ABB}$ & Dessert \\
\hline Sukali Ndiizi & & Kamaramasenge & $\mathrm{AAB}$ & Dessert \\
\hline
\end{tabular}

+ Cultivars introduced under TC; * Nearly extinct and still desired banana cultivars

known as matooke; dessert banana-eaten when ripe; brewing banana for making local beer known as tonto, and roasting banana. Most of these belong to the East African Highland genome group (AAA-EA), which according to Karamura et al. (2012) are grouped into five major clone sets namely: Musakala, Nakitembe, Mbidde, Nfuuka, and Nakabululu-each one with unique characteristic attributes. The cooking-type group has the highest diversity in respect to cultivars than the other groups. Cultivars for brewing have high tannin content and astringent fruit (Hamilton et al. 2016). In addition to the economic use (food, or brewing), the cultivars have multiple cultural uses that compel a single farmer to grow several cultivars in the same plantation. 
Table 2 presents the cultivars found in the study area and those that were available through TC. It is noted that the cultivars supplied through TC represent only a very small proportion of the cultivars that farmers currently grow. Farmers make choices of cultivars planted to meet their diverse uses including the cultural values. This implies that even farmers who choose to grow the cultivars supplied through TC also grow other cultivars (in the same plantation) to include a range of banana uses. This practice encourages cross-infection thereby defeating the intention of controlling BXW using TC technology. We discuss how the different uses of banana are embedded in the culture and traditional practices of the Baganda with a view of elucidating how the TC planting materials may be ineffective in controlling BXW.

\section{Banana cultivars as food}

As food, bananas are consumed in different forms; as matooke, ${ }^{5}$ roasted (plantain), dessert, juice/traditional beer. Among the cooking varieties, farmers may prefer specific ones for their own consumption while others are grown for the market (also see Bagamba et al. 2006; Kitanishi et al. 2018). Those for family consumption may not be high yielding but are preferred for their taste, color (yellowish) and texture (soft). Food in the cultural context wields power to bring joy and happiness to the consumer (Lee 2011). Culinary practices in Uganda call for different kinds of banana for different kinds of dishes/beverages that bring pleasure or good taste. However, the matooke Cultivars introduced under TC (Mpologoma, FHIA-01 and FHIA-17) were reported to have undesirable color (whitish) when cooked, with no aroma and a 'flat' taste. This finding is in tandem with Kikulwe et al. (2011) who found out that consumers in Uganda are willing to purchase genetically modified (GM) banana cultivars only if they contain tangible benefits, such as agronomic, nutritional and taste traits. Similarly, according to Schnurr et al. (2020), if banana cultivars targeted for biofortification to address vitamin A deficiency in children under five and lactating mothers in Uganda are not the preferred traditional varieties, such biofortified cultivars are less likely to be adopted by consumers.

For some cultural events like traditional marriage ceremonies known as ' $k$ wanjula', the specific cultivar (Nakitembe) is used to prepare a special meal for the groom's family and/or presented as gift to the bride's family. Its stem and leaves also possess medicinal properties useful for treating menstrual pains and infants' skin diseases (ekyogero). Out of the seven cultivars that constitute the Nakitembe clone-set

\footnotetext{
${ }^{5}$ Matooke is prepared by peeling green fingers of a mature bunch. They are wrapped in banana leaves, steamed, and mashed. Different varieties present different taste, flavour, colour, texture and aroma.
}

for example, only one cultivar was supplied through TC. This constrains the diversity of cultivars within a particular clone-set that is used for several cultural functions. It is noted that cultivars supplied through TC were based on commercial considerations (bunch and finger size) focusing on the market value and household income (also see Bagamba et al. 2006; Kitanishi et al. 2018) and inadequate attention was paid to cultural significance. In Central Uganda, farmers choose cultivars not only for food and income but also the cultural practices among the Baganda. Even for food, not all commercial cultivars would be preferred for household consumption. The available TC planting materials do not provide a wide range of choices to serve farmers' diverse uses and preferences. For example, one of the farmers in an FGD in Luweero District stated:

Not all cooking-type cultivars make good matooke.

Some cultivars are better and as a farmer who has a choice, I would prefer matooke from specific cultivars like Nakitembe, Mukubyakonde, Muziranyama and Nakawere even though these may not be the best commercial varieties (October, 2016).

Other cooking cultivars have special cultural significance. For example, the Ndibwabalangira literally by its name implies, it is best for royalty-meaning it has attributes that only royalty merits. Another variety, Nakawere by its name implies it is best for mothers that have just given birth, probably due to its nutritional value. Atwalirannyina's name implies that the cultivar is the best gift one can give to their mother because of its taste, large finger and bunch size. Banana cultivars also symbolize social status and therefore focusing solely on commercial value in selecting TC-produced cultivars will also encourage growing local cultivars infected with BXW alongside the TC varieties, thus compromising overall BXW control.

Traditional beer (omwenge omuganda- tonto, akaliga, kwete, omusetulo and enguli) is central and used at all cultural and social functions whether it is a celebration or funeral or other cultural ceremonies. Brewing banana cultivars are also used to produce juice (omubisi). None of the traditional brewing cultivars were supplied through TC, instead new hybrid cultivars (FHIA-25 and KM5) were provided, to which farmers are unaccustomed. The scientific explanation was that the local brewing cultivars are highly susceptible to BXW (Adikini et al. 2013; Tripathi et al. 2009) but at the same time farmers claim new cultivars have low sugar content and do not make good quality beer. It is not possible for farmers to abandon such an important cultural value and will continue to plant their local cultivars even though this practice favors cross-infection and hence BXW spread.

Though in varying proportions, all farmers grow a wide range of cultivars in the same plantation to meet both their 


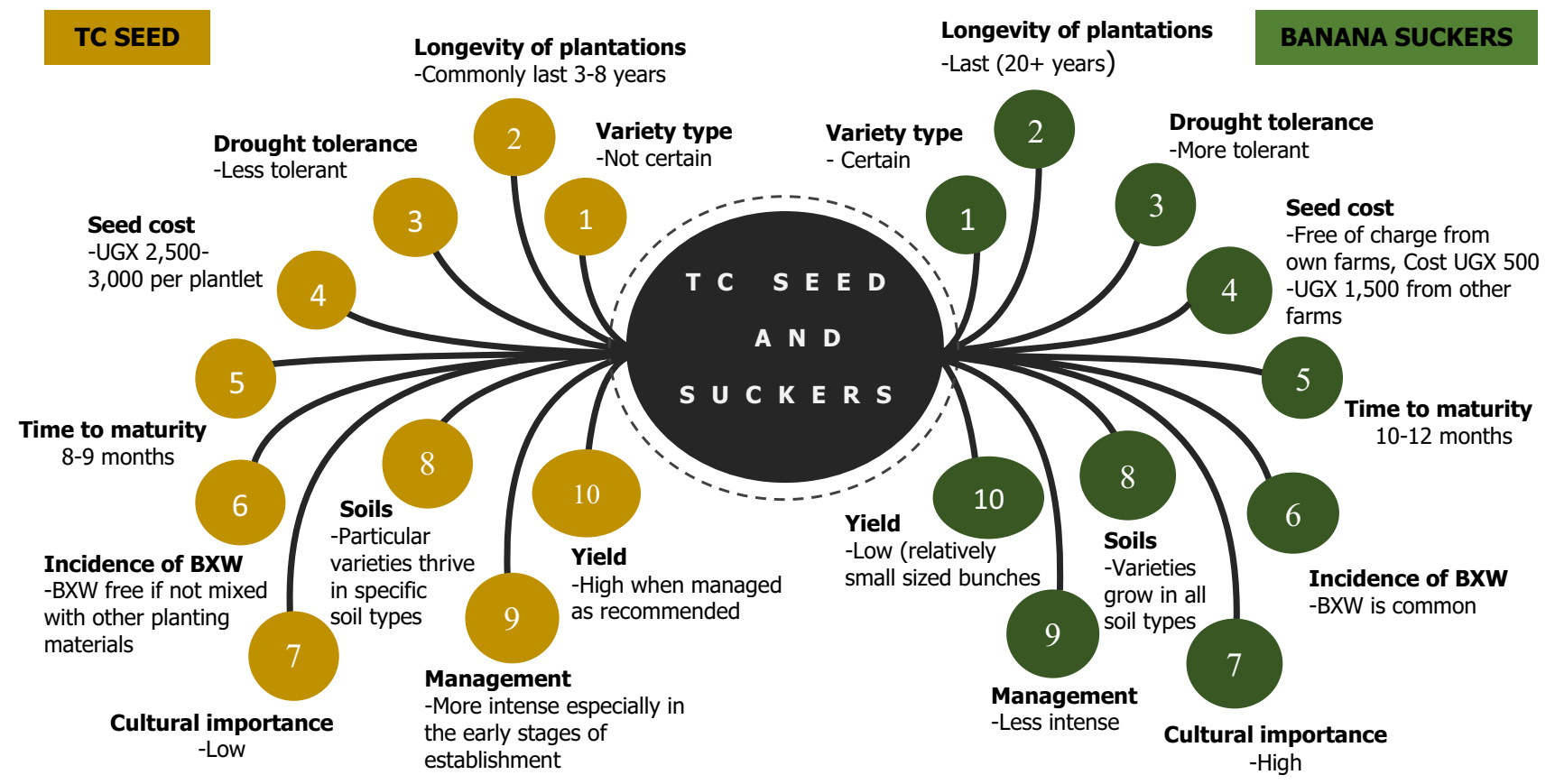

Fig. 4 Farmers' comparison by performance of TC banana seed and suckers

economic and socio-cultural interests (Gold et al. 2002; Karamura et al. 2012). Specific to the central region, banana plantations are at times split into part for the male and part for the female household members - the former producing mainly for the market and the latter for home consumption and including cultural uses (Karamura et al. 2004). In these two parts, the cultivars may be different. Diversity is also desirable for food security and sustainability of the food system (Bioversity International 2017). Nonetheless, it is difficult to maintain this diversity with TC due to high cost of propagation and yet some cultivars may not be in sufficiently high demand to be economically viable for any TC business. Our findings are consistent with previous studies (Kabunga et al. 2012; Mmurongo et al. 2018) postulating cultural values, higher labor and input requirements as key barriers to TC use. However, these findings notably diverge with Mukasa (2018) who associates limited uptake of innovations in Tanzania and Uganda with long distances- limiting farmer accessibility to agricultural technologies. This study is nested in a specific cultural context and cannot be generalized, the same way that other studies need not overgeneralize. Effective BXW management and promotion of $\mathrm{TC}$ technology require context-specific considerations especially for communities where banana is a traditional crop.

Additionally, in our study men preferred growing high yielding cultivars with big fingers and bunches (e.g., Mpologoma, Musakala, Kisansa) for the market, which are mainly promoted through TC. However, women preferred cultivars that yield multiple bunches (e.g., Nakabululu,
Nakabinyi, Mukubyakonde) continuously throughout the year (Plate 1). These cultivars produce small- to mediumsized bunches with perceived good taste (in relation to flavor, color, texture and aroma), but there are hardly available through TC. A possible explanation for men's interest in high-yielding cultivars is that men traditionally control household finances (e.g. for education, healthcare, and investments) while women customarily ensure their household food security, a key cultural role especially in central Uganda (Sanya et al. 2020). Results also showed that women prefer traditional cultivars with soft leaves (e.g., Kayinja, Bogoya, Ndizi) important for steaming food and preparing traditional dishes locally known as mpombo (see Plates 2 and 3). Leaves of introduced TC cultivars such as FHIA 17 were mentioned to be very large and brittle, seldom used during traditional ceremonies like burial ceremonies and last funeral rites when large amounts of matooke are prepared. In such situations, the large leaves are the final wrapping material to cover the huge mounds of food. In terms of division of labour in banana production in central Uganda, men mostly perform labour-intensive activities such as digging holes, removal of unwanted suckers, stump removal, harvesting for the market and transportation of large bunches. The women carry out activities requiring less physical strength such as weeding, removal of old leaves and fibres and harvesting bunches for food. Our findings resonate with Rietveld et al. (2016) whose results show different roles of men and women among banana-producing households in 
South Western Uganda. To foster uptake of TC banana, especially among women, it is imperative that promoters of TC technology factor in cultivar diversity and womenpreferred attributes in their promotion campaigns.

In comparison of performance between TC seed and suckers, farmers had perceptions that tended to disadvantage the use of TC seed as outlined in Fig. 4.

From their own experience, farmers observed that any new cultivar supplied through TC required more intensive management including greater use of fertilizers/manure, mulching and water availability than in the traditional system. It is noted that since these are largely selected for high yields, their crop nutrient requirements are also higher for optimum performance. If managed the same way as the local varieties, they may yield even less than the local varieties. This increases management costs in addition to the high seed cost. In this perspective, TC plantlets are considered to offer no relative advantage, complicated to grow, and require changes in practices which have to be accompanied by new management information. Some farmers who planted TC seed complained about not being able to precisely identify the cultivars before planting unlike for the suckers. It is possible that plantlets are mixed up in the nursery or mislabeled and the farmer may only realize after a long time. Bananas being a perennial crop, farmers have to bear with the undesired effects for several years. This complexity exists not only at the farm level, but also across in the entire seed system, posing a greater risk where a farmer may have mistakenly planted an unintended variety.

One of the farmers expressed disappointment with TC materials as follows:

These are the kind of 'plants' (referring to TC) that can be easily identified from your plantation due to poor growth characteristics, in spite of the fertilizers, labor, capital and time you spend on them. They simply 'refuse' to grow! (FGD Mukono District November 2016).

It is also possible that such disappointment could be due other factors such as weevil damage (also see Robinson 1996) and therefore a package of knowledge and management practices is required to effectively grow TC bananas.

Additionally, farmers indicated TC seed established plantations did not last as long as those planted with suckers. In the words of one farmer:

We got fifteen (15) free TC plantlets and a bag of manure each to establish a demo TC plantation. We were also encouraged to plant 10 local banana cultivars alongside the TC plants for comparison. However, due to prolonged dry spells we experienced in the recent past, currently, all the TC plants wilted and dried but the 10 local cultivars survived and still exist. (FGD Mukono district, November 2016).

This may be attributable to challenges in the tissue culture micro propagation process related to somaclonal variations (Damasco et al. 1996), poor physiology (George 1996) and the lack of soil micro-biota. As established by Nowak (1998), these factors can render the performance of TC seed to be poor, especially under environmental stress. It is also argued that the survival of TC seed at establishment may be hampered by climatic stress since plantlets are devoid of food reserves (Kavoo-Mwangi et al. 2014). Besides, the performance of commercial cultivars (big bunches and big fingers) as is the case with newly introduced TC seed requires higher soil fertility to sustain their production. Nevertheless, the soils in the central region have for various reasons considerably deteriorated in fertility (Zake et al. 2000; Nyombi 2013) which can contribute to a shorter survival period of TC-established plantations. In such aspects, there is lack of demonstrated relative advantages that TC seed has over suckers to convince farmers to take up TC planting materials.

\section{Banana as a cultural artefact}

Specific banana cultivars were used for different cultural practices. The banana in this case is not just a crop but also a cultural artefact. Propagation of TC planting materials would therefore have to accommodate the cultural use of banana and supply essential varieties. Table 3 presents the cultural uses of five different banana cultivars in central Uganda.

These cultural practices are performed at household level, thereby requiring every household to have these varieties. Such cultivars are not among those supplied through TC because they are not of commercial value. A farmer in Nambi village emphasized:

It is almost mandatory that in every household, each banana plantation will have cultivars such as Nakitembe, Embidde enganda and even Gonja. (October 2016).

These cultivars are used in several cultural practices related to child-birth ceremonies, marriage ceremonies, funerals and funeral rites. Even with current modernization, it is common for women to give birth at home or within the community. Traditionally, when a mother gives birth at home, the placentas are not thrown away as they are symbolic to the new-born child. For example, if a baby girl is borne, the placenta is wrapped in cloth by family and/or clan members and placed in a mat of Nakitembe cultivars (Plate 1). For a baby boy, the placenta is placed in a mat of Embidde enganda or Kayinja varieties. It is then covered with herbs- 'bombo' [Mormodica foetida Schum.] 
Table 3 Banana cultivars and their cultural practices in central Uganda

\begin{tabular}{ll}
\hline Variety & Cultural importance \\
\hline Nakitembe & Disposal of placentas for newly borne baby girls \\
& Treating menstrual pains especially for young girls experiencing menstruation for the first time \\
& Herbal baths for baby girls \\
& Practices for celebrating birth of twins \\
& Cleaning of the dead (females) before burial (Mid rib of Nakitembe pseudo stems crushed and used to 'wash' the deceased's \\
& face. Believed to keep away the spirits of the dead) \\
& Marriage ceremonies \\
& -Leaves used in matooke preparation for in-laws during introduction (Kwanjula) ceremonies \\
& -Leaves important for herbal baths of brides before marriage \\
& -Ceremonial meal to husband prepared by bride after honeymoon \\
Embidde enganda & Disposal of placentas of newborn baby boys \\
(Kabula \& Nsowe) & Cleaning of the dead (males) before burial. Mid rib of pseudo stems crushed and used by relatives to 'wash' the deceased's \\
& face \\
& Herbal bath 'Ekyogero' for male babies \\
& Leaves used for herbal baths of bridegrooms \\
& Used in practices to divert rains. A stick is pierced through a banana finger and roasted in a fireplace ('Ekyoto') \\
& Used in practices for celebrating last funeral rites and burial ceremonies. Dry leaves 'essanja' laid on the ground and the \\
Kayinja & casket is placed on it. The dry leaves are also used to make huts for household members and guests at the last funeral rites \\
& Used in cleansing ceremonies. Believed to cleanse curses and bad omen
\end{tabular}

Table 4 Banana cultivars and their associated beliefs in central Uganda

\begin{tabular}{|c|c|}
\hline Variety & Associated beliefs \\
\hline Nakabinyi & $\begin{array}{l}\text { Banana bunches not fit to be given as gifts to in-laws since shape of male bud elongates in the sem- } \\
\text { blance of a male human reproductive organ }\end{array}$ \\
\hline Mbwazirume & $\begin{array}{l}\text { Believed to 'change' to Nakitembe (losing the reddish color of the mid ribs of its banana leaves) if its } \\
\text { leaves are used in food preparation }\end{array}$ \\
\hline Siira & Transforms to Nfuuka cultivar if leaves are used in food preparation \\
\hline $\begin{array}{l}\text { Embidde enganda } \\
\text { (Kabula \& Nsowe) }\end{array}$ & Believed to be the 'husband' of a plantation. The first cultivar planted in the middle of a plantation \\
\hline Embidde (Kabula \& Nsowe)\& Kayinja & Considered 'male' varieties \\
\hline Nfunka & Changes to another cultivar if knife used to cut animal meat is used to cut the leaves \\
\hline $\begin{array}{l}\text { Nakitembe } \\
\text { Embidde enganda/Kayinja }\end{array}$ & Bestow blessings to infants when used for herbal baths \\
\hline $\begin{array}{l}\text { Tissue culture } \\
\text { banana varieties }\end{array}$ & $\begin{array}{l}\text { Hybrids which have been modified from their original form and even some farmers have perceptions } \\
\text { that they are GMOs }\end{array}$ \\
\hline
\end{tabular}

and 'lweza' [Aerva lanata (L.) Juss. ex Schult.] that connote peace and blessings upon the newborn.

The Gonja cultivar is used in cleansing ceremonies and restoring peace and harmonious relationships in families or in practices for reconciling individuals and families. Literally translated, Gonja, means 'soften' implying that when people share Gonja in a peace-making ceremony, the parties involved soften and become more tolerant of each other. The leaves of Kayinja, Ndiizi and Bogoya are preferred for preparing a special sauce (luwombo) or matooke before they are steamed. In particular, luwombo is special way of preparing sauce for respectable guests such as inlaws (Plate 2 and 3).

\section{Beliefs associated with bananas}

Farmer beliefs associated with banana cultivars (Table 4) guide farmers' use and cultural connections with the cultivars that they grow. These relate to taboos and norms that are strongly held and observed in relation to some banana varieties. For example, in one of the FGDs in Mukono district the TC nursery operator specified:

Some time ago I had the Gonja cultivar among the TC planting materials and that season, my sales were very low. A community member advised that my sales were very low because of the bad luck associ- 
Table 5 Medicinal uses of banana cultivars in central Uganda

\begin{tabular}{|c|c|}
\hline Variety & Disease/ailment \\
\hline \multirow{5}{*}{$\begin{array}{l}\text { Embidde } \\
\text { enganda } \\
\text { (Kabula \& } \\
\text { Nsowe) }\end{array}$} & $\begin{array}{l}\text { Diarrhea } \\
\text {-Sap from suckers mixed with herbs and drank }\end{array}$ \\
\hline & $\begin{array}{l}\text { Treatment of umbilical cords in infants } \\
\text { - Sap from suckers placed on the umbilical cords of infants }\end{array}$ \\
\hline & $\begin{array}{l}\text { Fractures in both humans and animals } \\
\text { - Sap from suckers used to set and massage fractured bones }\end{array}$ \\
\hline & $\begin{array}{l}\text { Snake bites } \\
\text { - Sap from sucker mixed with tree herbs and drank }\end{array}$ \\
\hline & $\begin{array}{l}\text { Abscesses } \\
\text { - Sap from sucker mixed with herbs, ant hill 'ekifulufu' soil and concoction smeared on boils }\end{array}$ \\
\hline \multirow[t]{5}{*}{ Gonja } & $\begin{array}{l}\text { Healing of umbilical cords in infants } \\
\text {-A finger is burnt, resultant ash gently rubbed on umbilical cords of infants }\end{array}$ \\
\hline & $\begin{array}{l}\text { Childbirth } \\
\text { - Mother in labor chews roots to hasten the child delivery process }\end{array}$ \\
\hline & $\begin{array}{l}\text { Colic in infants } \\
\text { - A mother of twins (Nalongo) weaves a small rope from banana fiber that is tied around the } \\
\text { waist of the infant }\end{array}$ \\
\hline & $\begin{array}{l}\text { Diarrhea in infants } \\
\text { - Fiber tied around waist of sick infant till the condition stops }\end{array}$ \\
\hline & $\begin{array}{l}\text { Mumps } \\
\text { - Banana fiber tied around the child's chest }\end{array}$ \\
\hline Kibuzi & $\begin{array}{l}\text { Wounds and skin infections } \\
\text { - Rachis cut into pieces, boiled and resultant liquid bathed or applied on wounds }\end{array}$ \\
\hline Nakamali & $\begin{array}{l}\text { Impotence in men } \\
\text { - Geotropic roots crushed, mixed with hot water and drank }\end{array}$ \\
\hline $\begin{array}{l}\text { Nakitembe, } \\
\text { Embidde } \\
\text { enganda \& } \\
\text { Kayinja }\end{array}$ & Skin diseases and epilepsy \\
\hline
\end{tabular}

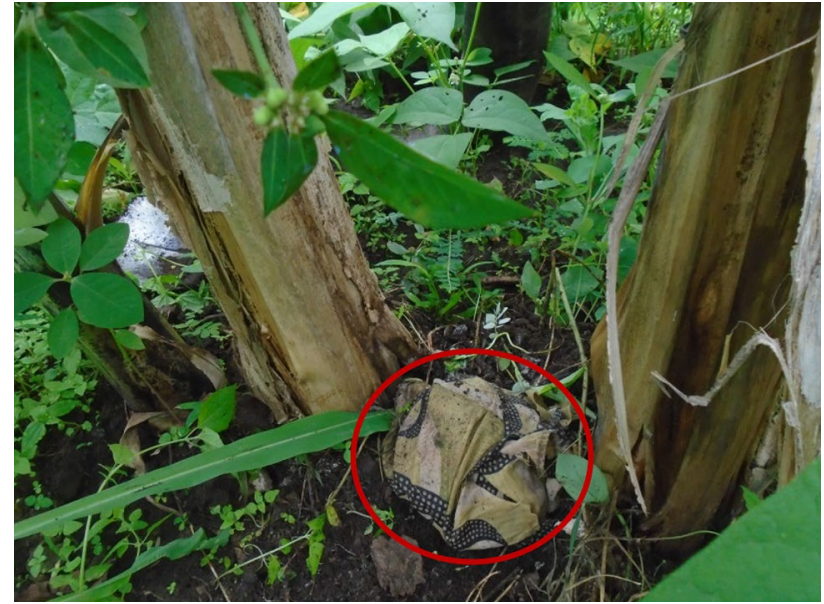

Plate 1 A placenta wrapped in cloth and placed in shallow hole between two 'Nakitembe' pseudo stems

ated with the Gonja cultivar and he cautioned that I get rid of them. When I did as advised, my sales went higher the next season. (November, 2016).
This finding implies that some cultivars such as Gonja are associated with bad luck and are not commonly grown in the region or where grown, caution is taken. For instance, it is believed that farmers have higher chances of experiencing lightning if they plant Gonja around their homesteads. As such, in homesteads where it is grown (most especially for use in performance of particular rituals), only a few mats are planted and precisely on the peripheries of plantations. Additionally, even buyers are keen not to carry Gonja among other bananas and to minimize on this effect, a finger of Gonja is placed under the vehicle wheel so that it is crushed prior to transportation. Unless going for burial, caution is taken by farmers not to consume Gonja or have anything to do with this cultivar as it is believed any anticipated success for the day will ultimately turn to failure.

Similarly, some banana cultivars are believed to 'transform' to other cultivars when specific norms are evaded. For example, Nambi is believed to change to Nakitembe when its banana leaves are used for cooking food. However, this is indicative of such cultivars belonging to the Nfuuka clone set (characterized by high susceptibility to morphological 


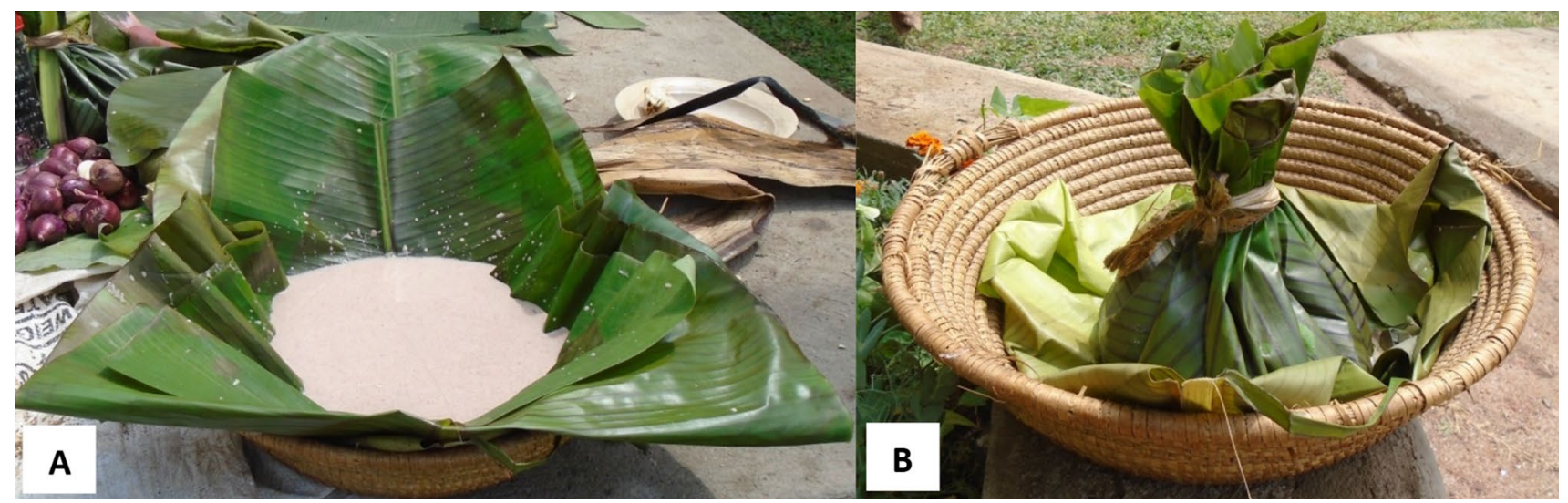

Plate 2 A-Preparing 'luwombo' with ground nut sauce: B-Groundnut sauce wrapped in 'empombo' and tied with a banana fiber, traditionally referred to as 'luwombo' ready to be steamed

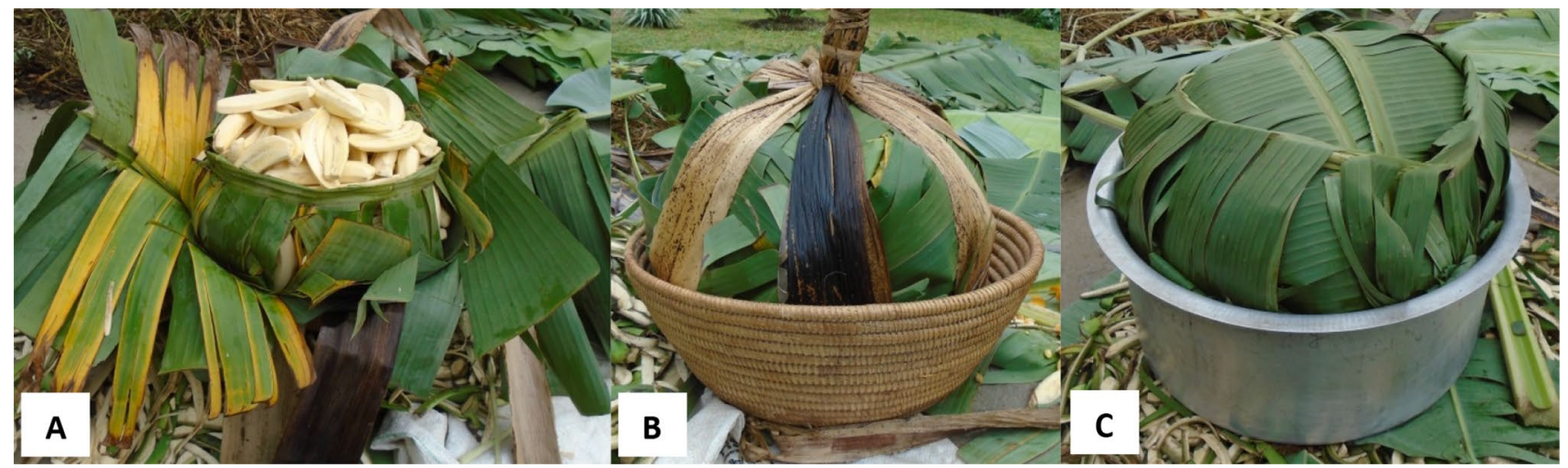

Plate 3 Preparing matooke the traditional way. A-Peeled cooking banana, 'matooke' placed in banana leaves; B-Matooke wrapped in banana leaves and tied with banana fiber; $\mathbf{C}$-Matooke covered with banana leaves in a saucepan ready to be steamed

change) (Karamura et al. 2012) and not necessarily because particular norms have been evaded. Banana cultivars are known to present superficial expressions of morphological traits which are often not stable and some cultivars as well show different phenotypic expressions under different ecological conditions (also see Karamura and Karamura 1994; Karamura 1999). It is also believed by farmers in the study communities that the TC planting materials are 'hybrids' meaning that such a cultivar has been modified from its original form; implying that such cultivars are not suitable for performing cultural functions and rituals. This points to farmers' perceived incompatibility of TC banana planting materials with their socio-cultural identity, which acts a significant barrier to using the technology in the study communities since tradition as a cultural value is compromised. On the contrary, TC-established cultivars are genetically similar with the original (local) cultivars from which they are cloned (Hrahsel and Thangjam 2013). The hesitation to take on TC planting materials is therefore partly attributed to inadequate information and understanding of processes of TC propagation on the part of the farmers.

\section{Banana as medicine}

Some banana cultivars are also used as medicine in the Baganda culture. Table 5 illustrates how these cultivars are used to treat various ailments. For instance, epilepsy in infants is treated through a ritual where the infant is bathed from a Mbidde mat. Whereas neither fire nor hot water are used, the leaves of the cultivar Mbidde should appear 'burnt/ scotched' after the ritual-a sign that the epileptic 'demon' is gone and if it does not, the child is not healed, and the procedure has to be repeated. On the contrary, piles in males is treated by placing a patient up on Mbidde's pseudostem (for females a Nakitembe pseudo stem is used) that has not flowered. S/he faces in the sun's direction and is gently lowered every morning and evening. It is believed that by the time the banana plant flowers, s/he will have healed. 
However, farmers indicated that TC cultivars do not harbor desirable traditional characteristics important for treatment/management of ailments. For example, a farmer expressed:

...Those TCs are not our own, they are 'adulterated' and cannot be used for our traditional medicine... (October 2016).

Another explained:

.. TCs lack traditional characteristics and we cannot use them for medicinal purposes. They make a swordlike corm beneath the mat rather than a semi-flat base that culturally is not acceptable ... (October 2016).

Worldwide, cultural systems recognize health and wellbeing of individuals' as being complex, combining spiritual and physical dimensions (Bodeker 1989; Fisher 2011). It is believed that both dimensions have to be harmoniously developed for the total well-being of an individual. In accordance with our findings, studies (Shibre et al. 2008; Degonda and Scheidegger 2012; Sorketti et al. 2013) have documented positive outcomes from traditional medicine in sub-Saharan Africa, a factor which could explain the popularity attributed to the treatment. Traditional medicine is often preferred over western medicine, being viewed as a culturally meaningful approach, easily accessible, affordable and at times given free (Degonda and Scheidegger 2012). In Uganda, estimates indicate that the ratio of traditional medicine practitioners to the population is $1: 700$, significantly contrasting with available trained medical personnel for whom the ratio is 1:8547 (Kasilo et al. 2010; Akol et al. 2018). These statistics point to the crucial role that traditional medicine still plays in the Ugandan health system.

Nevertheless, as indicated above and earlier (Table 4), farmers' beliefs that TC materials are genetically modified (or hybrids) was mentioned to be an impediment to farmer use of banana cultivars generated from TC as medicinethey are not trusted for potency of their medicinal properties. Elsewhere, authors (Mcrobert and Rickards 2010; Jha et al. 2020) have shown that farmers' beliefs and opinions are at the center in their decision-making regarding uptake of agricultural technologies. For this reason, farmers in the study communities will continue to plant their local materials even alongside the TC seed, and thereby sustaining the risk of BXW through cross-contamination.

\section{Conclusion and implications}

This study highlights how culture and traditions may constrain uptake and effectiveness of TC banana planting materials as a strategy for controlling BXW in central Uganda and in the context of the Baganda culture. Findings indicate that farming is indeed 'agri-culture', not merely economic or scientific. Culture is integral to agriculture and has to be considered in all agricultural technologies. The cultural uses of banana in central Uganda are anchored in diversity of cultivars where different cultivars are used for specific cultural practices, and yet TC promotes only a few commercial varieties. In the attempt to accommodate their diverse uses of banana, farmers will plant TC seed alongside their local preferred varieties, which facilitates cross-infection of BXW. To enhance effectiveness of TC in control of BXW, it is important to identify the cultivars of cultural importance and broaden the range of TC cultivars available to the farmers. It is imperative that a wide range of cultivars through TC seed are provided which fit the socio-cultural context and satisfy the multiple functions of banana to foster greater uptake. Even so, TC seed producers (e.g. TC laboratories and TC nursery operators) should consider this whilst increasing seed supplies to break-even in their businesses. Only a few plantlets (one or two for a farmer) suffice for cultural purposes and as such not all cultivars may be in sufficiently high demand.

Farmers' beliefs that TC seed is genetically modified and that such cultivars would not be suitable for cultural practices also constrain the uptake of TC materials. Increased awareness creation is needed among banana farmers in central Uganda regarding the processes of TC and the non-interference of the propagation technique with the genetic composition of the variety. The commercial cultivars promoted through TC are also heavy feeders and require soil fertility improvement practices such as use of organic manure or fertilizers to sustain productivity. Otherwise, farmers believe that their soils are not suitable for TC banana as productivity declines faster compared to their traditional varieties. It is therefore important that to disseminate TC technology widely, NGOs, local extension staff, the TC laboratories and nursery operators all better package the technology with detailed information showing its production process, advantages and disadvantages, and agronomic practices. This can be disseminated through farmer-preferred information dissemination pathways such as radios as reported by Kikulwe et al. (2019).

The cultural dimensions of bananas in central Uganda present a more complex context for technology uptake than anticipated by many stakeholders in the industry. Such circumstances call for deeper engagement and involvement of men and women farmers who are the intended users of the technology to understand their unique context in order to tailor the technology to the diverse interests and uses of the products promoted. In this case, the tension between gender, cultivar diversity, cultural practices, and commercialization of banana hinders using TC plantlets to control BXW. The results not only provide a 'reality check' but also highlight the importance of farmer engagement in the development 
and promotion of any agricultural-related innovation. For sustainable use of agricultural innovations such as TC, it is important that breeders and TC plantlet producers not only put into consideration economic and biological attributes of targeted crops, but also gender and cultural aspects. This will help promoters of agricultural technologies to diversify gender-responsive cultivar attributes required by end-users, and in turn will increase adoption of such innovations. Future efforts towards the control of pests and diseases would benefit from more location-specific and holistic approaches that integrate gender and cultural dimensions alongside clean seed.

It should, however, be noted that this is a field note and that many important questions remain unanswered due to limitations of methods and space for publication. For instance, the "politics" of TC varieties, whether the farmers see themselves as upholding local traditions in light of globalization, or are experimenting with TC technologies to maintain good relations with government technocrats for benefits is not captured. Therefore, it is highly recommended that future research should consider incorporating such aspects to develop a better understanding of the political factors that might influence uptake of agricultural innovations. In addition, the authors recommend a systematic and scientific inquiry regarding the medicinal values of some banana cultivars and to address farmer concerns about TC innovations being 'adulterated'.

Acknowledgements This research was undertaken as part of the CGIAR Research Program on Roots, Tubers and Bananas (RTB). We are grateful to the banana farmers in the study communities who participated in this study. Our appreciation goes to Emmanuel Ngolobe, Eva Tereka, Ruth Nakintu, Ssebunya Mohammed Ali and Ssenyonjo Michael for their participation in data collection. Mrs Justine Kyobe, Mrs Sserunkuma Margaret (RIP), Ms. Nakafu Margaret Kyasa (Mukono district) and Mrs Kiggundu (Luweero district) are appreciated for their role in mobilizing the respondents. We also thank the reviewers for their constructive comments. We further acknowledge the contribution of Vincent Johnson in providing English language editing to improve the readability of the text.

Funding This research was funded by the CGIAR Research Program (CRP) Roots Tubers and Bananas (RTB) through the 'RTB Seed Systems Project' Grant No. 96202-500-A1050-B100461-C100078UGAND and the Regional Universities Forum for Capacity Building in Africa (RUFORUM) with funding from the Carnegie Corporation of New York grant number RU/2016 /Carnegie/DRG/009.

Open Access This article is licensed under a Creative Commons Attribution 4.0 International License, which permits use, sharing, adaptation, distribution and reproduction in any medium or format, as long as you give appropriate credit to the original author(s) and the source, provide a link to the Creative Commons licence, and indicate if changes were made. The images or other third party material in this article are included in the article's Creative Commons licence, unless indicated otherwise in a credit line to the material. If material is not included in the article's Creative Commons licence and your intended use is not permitted by statutory regulation or exceeds the permitted use, you will need to obtain permission directly from the copyright holder. To view a copy of this licence, visit http://creativecommons.org/licenses/by/4.0/.

\section{References}

Adikini, S., F. Beed, G. Tusiime, L. Tripathi, S. Kyamanywa, M. Lewis-Ivey, and S.A. Miller. 2013. Spread of Xanthomonas campestris pv. musacearum in banana plants: implications for management of banana Xanthomonas wilt disease. Canadian Journal of Plant Pathology 35 (4): 458-4681.

Akol, A., K.M. Moland, J.N. Babirye, and I.M.S. Engebretsen. 2018. "We are like co-wives": Traditional healers' views on collaborating with the formal Child and Adolescent Mental Health System in Uganda. BMC Health Services Research 18 (1): 1-9.

Bagamba, F., E. Kikulwe, W.K. Tushemereirwe, D. Ngambeki, J. Muhangi, G.H. Kagezi, and S. Green. 2006. Awareness of banana bacterial wilt control in Uganda: 1. Farmer's perspective. African Crop Science Journal 14 (2): 157-164.

Bioversity International. 2017. Mainstreaming agrobiodiversity in sustainable food systems: Scientific foundations for an Agrobiodiversity Index. Bioversity International, Rome, Italy.

Blomme, G., K. Jacobsen, W. Ocimati, F. Beed, J. Ntamwira, C. Sivirihauma, F. Ssekiwoko, V. Nakato, J. Kubiriba, L. Tripathi, and W. Tinzaara. 2014. Fine-tuning banana Xanthomonas wilt control options over the past decade in East and Central Africa. European Journal of Plant Pathology 139 (2): 271-287.

Blomme, G., H. Mukasa, F. Ssekiwoko, and S.J. Eden-Green. 2005. On-farm assessment of banana bacterial wilt control options. African Crop Science Proceedings. 7: 317-320.

Blomme, G., W. Ocimati, C. Sivirihauma, L. Vutseme, B. Mariamu, M. Kamira, B. van Schagen, J. Ekboir, and J. Ntamwira. 2017. A control package revolving around the removal of single diseased banana stems is effective for the restoration of Xanthomonas wilt infected fields. European Journal of Plant Pathology 149 (2): 385-400.

Braga, C. 2001. “They're squeezing us!” Matrilineal kinship, power and agricultural policies: Case study of Issa Malanga, Niassa Province, in Strategic women gainful men: Gender, land, and natural resources in different rural contexts in Mozambique, edited by $\mathrm{R}$ Waterhouse \& C Vijfhuizen. Maputo: Imprensa Universitária.

Braun, V., and V. Clarke. 2006. Using thematic analysis in psychology. Qualitative Research in Psychology 3 (2): 77-101.

Bodeker, Gerard C. 1989. Traditional knowledge and modem health care: An analysis of W.H.O.'s training policy in traditional medicine in light of India's experience with Ayurveda. $\mathrm{PhD}$ Dissertation, Harvard University.

Chandra, Y., and L. Shang. 2019. Inductive coding. In Qualitative research using $R$ : a systematic approach, 91-106. Singapore: Springer.

Cori, V.D, Kikulwe, E., Kozicka, M., and Gotor, E. 2018. Understanding the economic impact of BXW and its management practices in East and Central Africa. Bioversity International, Rome, Italy (p. 16)

Damasco, O.P., G.C. Graham, R.J. Henry, S.W. Adkins, M.K. Smiths, and I.D. Godwin. 1996. Random amplified polymorphic DNA (RAPD) detection of dwarf off-types in micropropagated Cavendish (Musa spp. AAA) bananas. Plant Cell Reports 16 (1-2): $118-123$.

Degonda, M., and P. Scheidegger. 2012. Traditional healing in Uganda: A statistical analysis of treatments by a group of traditional healers. African Journal of Health Sciences 20 (1-2): 50-55.

Dotto, J., A.O. Matemu, and P.A. Ndakidemi. 2019. Nutrient composition and selected physicochemical properties of fifteen Mchare 
cooking bananas: A study conducted in northern Tanzania. Scientific African 6: 00150.

Dubois, T., Y. Dusabe, M. Lule, P. Van Asten, D. Coyne, J.C. Hobayo, S. Nkurunziza, E. Ouma, N. Kabunga, M. Qaim, and E. Kahangi. 2013. Tissue culture banana (Musa spp.) for smallholder farmers: Lessons learnt from East Africa. Acta Horticulturae 986: 51-59.

Eden-Green, S. 2004. How can the advance of banana Xanthomonas wilt be halted? Info Musa 13 (2): 38-41.

Edmeades, S., Smale, M., and Karamura, D. 2015. Biodiversity of bananas on farms in Uganda.

Fisher, J. 2011. The four domains model: Connecting spirituality, health and well-being. Religions 2 (1): 17-28.

George, E.F. 1996. Plant propagation by tissue culture. Part 2: In practice. Plant propagation by tissue culture (Ed. 2).

Gold, C.S., A. Kiggundu, A.M.K. Abera, and D. Karamura. 2002. Diversity, distribution and farmer preference of Musa cultivars in Uganda. Expl Agric. 38: 39-50.

Gotor, E., V. Di Cori, T. Pagnani, E. Kikulwe, M. Kozicka, and F. Caracciolo. 2020. Public and private investments for banana Xanthomonas Wilt control in Uganda: The economic feasibility for smallholder farmers. African Journal of Science, Technology, Innovation and Development 2: 1-12.

Hamilton, A.C., D. Karamura, and E. Kakudidi. 2016. History and conservation of wild and cultivated plant diversity in Uganda: Forest species and banana varieties as case studies. Plant Diversity 38 (1): 23-44.

Hardisson, A., C. Rubio, A. Baez, M. Martin, R. Alvarez, and E. Diaz. 2001. Mineral composition of the banana (Musa acuminata) from the island of Tenerife. Food Chemistry 73 (2): 153-161.

Haslinda, W.H., L.H. Cheng, L.C. Chong, and A.N. Aziah. 2009. Chemical composition and physicochemical properties of green banana (Musa acuminate $\times$ balbisiana Colla cv Awak) flour. International Journal of Food Sciences and Nutrition 60 (4): 232-239.

Hrahsel, L., and R. Thangjam. 2013. Strategies for large-scale production of commercially important banana varieties of Mizoram, India, using plant tissue culture. Science Vision 13: 3.

Idang, G.E. 2015. African culture and values. Phronimom 16 (2): 97-111.

Jha, S., H. Kaechele, M. Lana, T.S. Amjath-Babu, and S. Sieber. 2020. Exploring farmers' perceptions of agricultural technologies: A case study from Tanzania. Sustainability 12 (3): 998.

Jogo, W., E. Karamura, W. Tinzaara, J. Kubiriba, and A. Rietveld. 2013. Determinants of farm-level adoption of cultural practices for banana Xanthomonas wilt control in Uganda. Journal of Agricultural Science 5 (7): 70-81.

Kabunga, N.S., T. Dubois, and M. Qaim. 2012. Heterogenous information exposure and technology adoption: The case of tissue culture bananas in Kenya. Agricultural Economics 43: 473-485.

Kalyebara, R., S. Wood, and P.M. Abodi. 2007. Assessing the potential impact of selected technologies on the banana industry in Uganda. An Economic Assessment of Banana Genetic Improvement and Innovation in the Lake Victoria Region of Uganda and Tanzania. IFPRI Research Report 155: 141-156.

Karamura, D.A. 1999. Numerical taxonomic studies of the East African highland bananas (Musa AAA-East Africa) in Uganda. IPGRI.

Karamura, D.A., and E.B. Karamura. 1994. A provisional checklist of banana cultivars in Uganda. Montpellier: INIBAP.

Karamura, D.A., Karamura, E.B., and Tinzaara, W. 2012. Banana cultivar names, synonyms and their usage in Eastern Africa, Bioversity International, Uganda. Cover photo: D.A Karamura Bioversity International-Headquarters Via dei Tre Denari 472a, 57.

Karamura, D., D. Mgenzi, E. Karamura, and S. Sharrock. 2004. Exploiting indigenous knowledge for the management and maintenance of Musa biodiversity on farm. African Crop Science Journal 12 (1): 67-74.
Karamura, E.B., F.L. Turyagyenda, W. Tinzaara, G. Blomme, A. Molina, and R. Markham. 2008. Xanthomonas Wilt (Xanthomonas campestris pv. musacearum) of bananas in East and Central Africa diagnostic and management guide. Kampala: Fountain.

Kasilo, O., Trapsida, J., Mwikisa, C., and Lusamba-Dikassa, P. 2010. An overview of the traditional medicine situation in the African region. The African health monitor, magazine of the World Health Organization regional Office for Africa (WHOAFRO).

Kavoo-Mwangi, A.M., E.M. Kahangi, E. Ateka, J. Onguso, and J.M. Jefwa. 2014. Integration of commercial microbiological products into soil fertility practices as a potential option for acclimatization and growth of TC banana in Kenya. Open Journal of Soil Science 4 (08): 259.

Kerr, R.B. 2012. Lessons from the old Green Revolution for the new: Social, environmental and nutritional issues for agricultural change in Africa. Progress in Development Studies 12 (2-3): 213-229.

Kikulwe, E. 2016. Banana tissue culture: Community nurseries for African farmers. In Case studies of roots, tubers and bananas seed systems, eds. Andrade-Piedra. J., Bentley J., Almekinders C., Jacobsen K., Walsh S., and Thiele G. et al. Lima: RTB Working Paper No. 2016-3. Chapter 12.

Kikulwe, E.M., J.L. Kyanjo, E. Kato, R.T. Ssali, R. Erima, S. Mpiira, W. Ocimati, W. Tinzaara, J. Kubiriba, E. Gotor, and D. Stoian. 2019. Management of banana Xanthomonas Wilt: Evidence from impact of adoption of cultural control practices in Uganda. Sustainability 11 (9): 2610.

Kikulwe, E., S. Okurut, S. Ajambo, K. Nowakunda, D. Stoian, and D. Naziri. 2018. Postharvest losses and their determinants: A challenge to creating a sustainable cooking banana value chain in Uganda. Sustainability 10 (7): 2381.

Kikulwe, E.M., J. Wesseler, and J. Falck-Zepeda. 2011. Attitudes, perceptions, and trust: Insights from a consumer survey regarding genetically modified banana in Uganda. Appetite 57 (2): 401-413.

Kilwinger, F.B.M., A.M. Rietveld, J.C.J. Groot, and C.J.M. Almekinders. 2019. Culturally embedded practices of managing banana diversity and planting material in central Uganda. Journal of Crop Improvement 1: 1-22.

Kitanishi, K., Y. Sato, S. Odani, K. Shikata-Yasuoka, and K. Komatsu. 2018. Distribution and marketing of bananas in southwestern Uganda: the impact of commoditization of bananas on local farmers. 山口大学教育学部研究論叢 67: 197-204.

Kubiriba, J., E.B. Karamura, W. Jogo, W.K. Tushemereirwe, and W. Tinzaara. 2012. Community mobilization: A key to effective control of banana xanthomonas wilt. Journal of Development and Agricultural Economics 4 (5): 125-131.

Kubiriba, J., and W.K. Tushemereirwe. 2014. Approaches for the control of banana Xanthomonas Wilt in East and Central Africa. African Journal of Plant Science 8 (8): 398-404.

Lee, M.Y. 2011. Food as a symbol. Symbols and Sandplay Therapy 12 (2): 9-23.

Lwandasa, H., G.H. Kagezi, A.M. Akol, J.W. Mulumba, R. Nankya, C. Fadda, and D.J. Jarvis. 2014. Assessment of farmers knowledge and preferences for planting materials to fill-gaps in banana plantations in southwestern Uganda. Uganda Journal of Agricultural Sciences 15 (2): 165-178.

Mbabazi, E.G., E.M. Kikulwe, J.L. Kyanjo, N. Mulumba, E. Kato, and E. Gotor. 2021. Has continued exposure to banana Xanthomonas Wilt worsened farmers' welfare over time? Evidence from bananaproducing households in Uganda. Journal of Agricultural Science 13: 11 .

McCampbell, M., M. Schut, I. Van den Bergh, B. van Schagen, B. Vanlauwe, G. Blomme, S. Gaidashova, E. Njukwe, and C. Leeuwis. 2018. Xanthomonas Wilt of Banana (BXW) in Central Africa: Opportunities, challenges, and pathways for citizen science and 
ICT-based control and prevention strategies. NJAS Wagening Journal of Life Science 86-87: 89-100.

Mcrobert, J., and L. Rickards. 2010. Social research: Insights into farmers' conversion to no-till farming systems. Extension-Farming Systems Journal 6 (43-52): 28.

Mmurongo, M., K.J. Wangai, T.J. Mwine, and O.F. Ayuke. 2018. Farmer-based dynamics in tissue culture banana technology adoption: A socio-economic perspective among small holder farmers in Uganda. African Journal of Agricultural Research 13 (50): 2836-2854.

Mukasa, A.N. 2018. Technology adoption and risk exposure among smallholder farmers: Panel data evidence from Tanzania and Uganda. World Development 105: 299-309.

Mulugo, L. 2021. Socio-cultural factors influencing farmer use of tissue culture banana seed in Central Uganda Doctoral dissertation, Makerere University.

Mulugo, L., F.B. Kyazze, P. Kibwika, B.A. Omondi, and E.M. Kikulwe. 2020. Seed security factors driving farmer decisions on uptake of tissue culture banana seed in Central Uganda. Sustainability 12 (23): 10223.

Nakato, G.V., W. Ocimati, G. Blomme, K.K.M. Fiaboe, and F. Beed. 2015. Comparative importance of infection routes for banana Xanthomonas wilt and implications on disease epidemiology and management. Canadian Journal of Plant Pathology 36 (4): 418-427.

Namukwaya, B., L. Tripathi, J.N. Tripathi, G. Arinaitwe, S.B. Mukasa, and W.K. Tushemereirwe. 2011. Transgenic banana expressing Pflp gene confers enhanced resistance to Xanthomonas wilt disease. Transgenic Research 21 (4): 855-865.

Ngambeki, D., Bashaasha, B, Abele, S., Kalyebara, R., and Mpiira, S. 2003. Status of banana marketing in Uganda. Paper presented at the IBMU Stakeholder workshop in Kampala, Uganda, September 2004.

Njau, N., M. Mwangi, R. Kahuthia-Gathu, R. Muasya, and J. Mbaka. 2011. Macropropagation technique for production of healthy banana seedlings. African Crop Science Conference Proceedings 10: 469-472.

Nowak, J. 1998. Benefits of in vitro "biotization" of plant tissue cultures with microbial inoculants. In Vitro Cellular \& Developmental Biology-Plant 34 (2): 122-130.

Nyombi, K. 2013. Towards sustainable highland banana production in Uganda: Opportunities and challenges. African Journal for Food, Agriculture, Nutrition and Development 13: 7544-7561.

Ocimati, W., H. Bouwmeester, J.C. Groot, P. Tittonell, D. Brown, and G. Blomme. 2019. The risk posed by Xanthomonas wilt disease of banana: Mapping of disease hotspots, fronts and vulnerable landscapes. PLOS ONE 14 (4): 0213691.

Ocimati, W., G.V. Nakato, K.M. Fiaboe, F. Beed, and G. Blomme. 2015. Incomplete systemic movement of Xanthomonas campestris pv. musacearum and the occurrence of latent infections in xanthomonas wilt-infected banana mats. Plant Pathology 64 (1): 81-90.

Rietveld, A.M., Ajambo, S., and Kikulwe, E. 2016. Economic gain and other losses? Gender relations and matooke production in western Uganda.

Robinson, J. 1996. Banana and plantains, 238. UK: CAB International.

Rock, J., and R. Schurman. 2020. The complex choreography of agricultural biotechnology in Africa. African Affairs 119 (477): 499-525.

Sanya, L.N., H. Sseguya, F.B. Kyazze, G.M. Diiro, and F. Nakazi. 2020. The role of variety attributes in the uptake of new hybrid bananas among smallholder rural farmers in central Uganda. Agriculture \& Food Security 9 (1): 1-13.

Schnurr, M.A. 2019. Africa's gene revolution: Genetically modified crops and the future of African agriculture. McGill-Queen's Press-MQUP.

Schnurr, M.A., L. Addison, and S. Mujabi-Mujuzi. 2020. Limits to biofortification: Farmer perspectives on a vitamin A enriched Banana in Uganda. The Journal of Peasant Studies 47 (2): 326-345.
Shibre, T., A. Spångéus, L. Henriksson, A. Negash, and L. Jacobsson. 2008. Traditional treatment of mental disorders in rural Ethiopia. Ethiopian Medical Journal 46 (1): 87-91.

Sorketti, E.A., N.Z. Zainal, and M.H. Habil. 2013. The treatment outcome of psychotic disorders by traditional healers in central Sudan. International Journal of Social Psychiatry 59 (4): 365-376.

Thomas-Sharma, S., A. Abdurahman, S. Ali, J.L. Andrade-Piedra, S. Bao, A.O. Charkowski, D. Crook, M. Kadian, P. Kromann, P.C. Struik, L. Torrance, K.A. Garrett, and G.A. Forbes. 2016. Seed degeneration in potato: The need for an integrated seed health strategy to mitigate the problem in developing countries. Plant Pathology 65: 3-16.

Tripathi, L., M. Mwangi, S. Abele, V. Aritua, W.K. Tushemereirwe, and R. Bandyopadhyay. 2009. Xanthomonas wilt: A threat to banana production in East and Central Africa. Plant Disease 93 (5): $440-451$.

Tripathi, L., and J.N. Tripathi. 2009. Relative susceptibility of banana cultivars to Xanthomonas campestris pv. musacearum. African Journal of Biotechnology 8 (20): 5343-5350.

Tushemereirwe, W., Kangire, A., Ssekiwoko, F., Offord, L.C., Crozier, J., Boa, E., Rutherford, M.A. \& Smith, J.J. 2004. First report of Xanthomonas campestris pv. musacearum on banana in Uganda. Plant Pathology 53(6):802.

Tushemereirwe, W.K., Kubiriba, J., Nankinga, C., Masanza, M., Muhangi, J., Ssekiwoko, F., and Karamura, E. 2009. Proceedings of the workshop on review of the strategy for the management of banana Xanthomonas wilt. Kampala, Uganda. pp. 25-35.

Uganda Census of Agriculture [UCA]. 2010. Summary Report on Uganda Census of Agriculture 2008/2009.

Uwamahoro, F., A. Berlin, H. Bylund, C. Bucagu, and J. Yuen. 2019. Management strategies for banana Xanthomonas wilt in Rwanda include mixing indigenous and improved cultivars. Agronomy for Sustainable Development 39 (2): 1-11.

Vercillo, S., V.Z. Kuuire, F.A. Armah, and I. Luginaah. 2015. Does the New Alliance for Food Security and Nutrition impose biotechnology on smallholder farmers in Africa? Global Bioethics 26 (1): 1-13.

Warren, C.R., R. Burton, O. Buchanan, and R.V. Birnie. 2016. Limited adoption of short rotation coppice: The role of farmers' socio-cultural identity in influencing practice. Journal of Rural Studies 45: 175-183.

Publisher's Note Springer Nature remains neutral with regard to jurisdictional claims in published maps and institutional affiliations.

Lucy Mulugo is a Lecturer in the Department of Extension \& Innovation Studies, Makerere University. Her research interests include Indigenous knowledge and traditional farming systems, food security, gender and natural resource management and agricultural innovation systems.

Paul Kibwika is an Associate Professor at Makerere University with research interests in agricultural knowledge systems; innovations management and social transformations; and adaptive management and sustainability. He is also a trainer and facilitator of institutional change, strategic planning and social skills enhancement.

Florence Birungi Kyazze is a Senior Lecturer at Makerere University with interests in research methods and statistics; program development and evaluation and community resource management innovations oriented towards climate change adaptation and livelihoods improvement.

Aman Omondi Bonaventure is an Epidemiologist, Associate Scientist in the Banana Research Programme; Sustainable Landscapes Initiative, Bioversity International. His research interests include managing invasive pests and diseases, vector borne disease and community 
approaches for the control of banana diseases and cropping and seed systems health.

Enoch Kikulwe is a scientist at Bioversity International. His current work is focusing on adoption and impact assessment of agricultural technologies and sustainable use of natural resources in smallholder crop systems of East and Southern Africa. He has vast experience in evaluating the suitability of crop productivity enhancing technologies and policies in different agro-climatic environments as well as performing rigorous econometric impact assessments of these technologies and policies on livelihoods, food and nutritional security. 